\title{
Ultraísmo, poesía naíf y humor en los primeros poemas de Dámaso Alonso: Poemas puros, poemillas de la ciudad
}

\author{
AdRIÁN RAMÍREZ RiAÑo \\ Universidad Complutense de Madrid
}

Resumen: En este trabajo se estudia la primera poesía de Dámaso Alonso, recopilada en Poemas puros, poemillas de la ciudad en 1921, a través del filtro estético de su época. Trataremos de averiguar la influencia formal de la primera vanguardia española, el ultraísmo, en el joven poeta y cómo se apropia de las técnicas novedosas (principalmente el juego de disposición textual) y las implementa en una poesía de corte personal. Junto con ello, la primera poesía alonsina no solo tiene como referente la estética novedosa, sino que, gracias a la poesía tradicional y al tono poético pesimista aporta elementos lúdicos y naíf. Además el humor juega un papel importante en estos poemas de tono más machadiano que ultraísta.

Palabras clave: Dámaso Alonso, poesía de juventud, ultraísmo, humor.

\section{Ultraism, Naïve Poetry and Humor in the Early Poetry of Dámaso Alonso: Poemas puros, poemillas de la ciudad}

Abstract: This article studies the early poetry of Dámaso Alonso, collected in Poemas puros, poemillas de la ciudad in 1921, through the esthetic filter of his era. We will try to find the influence of the first Spanish avant-garde, ultraism, on the young poet and how he appropriates new techniques (mainly the game of textual dispositions) and implements them in his personal style of poetry writing. Furthermore, his early poetry not only uses as a reference the novel esthetic, but also contributes, through the traditional poetry and a pessimistic poetic tone, elements that are playful and naïve. In addition, the humor plays an important role in these poems with a tone that resembles more Antonio Machado than the ultraists.

Keywords: Dámaso Alonso, youth poetry, ultraism, humor. 


\section{INTRODUCCIÓN}

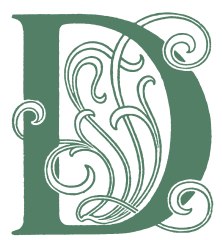

ámaso Alonso en su juventud era un poeta de su tiempo. En sus primeros poemas se observa la influencia de todas sus lecturas, pero también la de la nueva poesía incipiente en aquella época. La fecha de impresión de los Poemas Puros, 1921, es importante para la concepción del mismo estéticamente. La poética ultraísta comienza a disolverse favoreciendo la poesía de corte puro. El Vltra que pretenden imponer en la poesía española nombres como Cansinos-Assens o Guillermo de Torre se diluye como una simple oda extravagante de un momento concreto. La palabra asepsia rondaba en los teoremas poéticos de todos los compañeros de grupo, como recuerda Alonso. No hay más que leer estas líneas que escribió tras la guerra sobre la importancia rompedora del ultraísmo para allanar el camino de los poetas de su grupúsculo (Alonso, 1969: 162-163):

Hubo, sí, un violento conato de rompimiento, que hay que considerar aparte. Se trata del ultraísmo, que, sin necesidad ahora de gran rigor histórico y para hablar brevemente, podemos considerar como un movimiento complejo, con matices que van desde el creacionismo hasta el dadaísmo. Se incuba es impulso a fines de la primera guerra europea; se extingue con los primerísimos años del segundo decenio del siglo. Esta conmoción estridente se presenta en plan de falange cerrada. Tiene unas cuantas veladas tumultuosas y unas cuantas revistas, a veces de nombre paradójico. Muere, y el único poeta que se le salva es el único que allí tenía verdadero genio: nuestro Gerardo Diego. Pero sería error no hablar de esa fuerza que no completó su órbita o querer negar su importancia.

Trajo aquel grupo más que su chillón y efímero entusiasmo: los experimentos realizados con la imagen (imagen múltiple, etc.), la actividad para ligar poéticamente elementos muy distantes entre sí, de la realidad, en fin, del ennoblecimiento del humor, mejor dicho, de cierta alegría deportiva y despreocupada, sí que, a mi manera de ver, fueron a dar por caminos subterráneos o por muy sutiles capilares a la generación de antes de la guerra. El ultraísmo, movimiento fracasado, alimenta, aunque sea en pequeña parte, una de las más intensas generaciones poéticas de nuestra historia.

Tal y como afirma Dámaso Alonso en estas páginas correspondientes a Una generación poética (1920-1936), el ultraísmo fue una corriente fugaz y poco 
productiva (solo se publicaron cuatro libros de estos autores) que marcó los caminos a la siguiente generación, que supo conjuntar la tradición con los nuevos modos. Los Poemas puros son un ejemplo de esa mezcla de elementos, desde del filtro de una poesía pura en cuanto a formal, en la que Alonso experimenta con los juegos ultraístas, hasta una poesía de corte machadiano e influjos de Juan Ramón Jiménez. El humor, además, es una base de la nueva estética, asociada con el juego y lo lúdico, que proviene de la unión de desencanto personal en el tono con toques pueriles en las canciones de tipo tradicional. Las técnicas de vanguardia son un matiz alejado de la estética machadiana para presentar en los textos una voz poética joven pero personal. Como opinan Duque Amusco y Velo García (Aleixandre y Alonso, 1993: XXVI) en estos primeros poemas de juventud se observan registros desde románticos a ultraístas, ya que Alonso experimenta, practica y aprende influido por las lecturas del momento.

\section{ULTRAÍSMO: JUEGO DE RUPTURA VERSAL Y CREACIÓN DE POEMAS PICTÓRICOS}

La influencia del ultraísmo en el primer Alonso es defendida por todos los críticos que se han acercado a sus poemas, aunque desde puntos de vista distintos: se admite como fuente, aunque su notoriedad es menor frente al tono machadiano. Pero el influjo del ultraísmo en estos primeros poemas no es tan difuso por diversos motivos. En primer lugar, Bonet (1995: 44) afirma que Dámaso Alonso mantenía contacto con Eugenio Montes, uno de los formantes del grupo de Vltra, por lo que es posible que tuviera relación con alguno de sus miembros. Además, se conoce que, junto con Vicente Aleixandre, decide mandar un poema a la revista Grecia, que es aceptado con el pseudónimo de Ángel Cándiz, en el número 41, el 29 de febrero de 1920. El texto ya evidencia la influencia de la nueva estética por su título, «Poema ultraísta», pero en él se encuentran componentes de carácter machadiano y personales típicos de los Poemas puros. Por esa razón, Francisco Javier Díez de Revenga (2001) en La poesía de vanguardia admite que Alonso, de una forma directa, compone sus Poemas puros desde la modernidad poética. En este poema observa notas novedosas como el tratamiento de la luna, del espacio, el irracionalismo de alguna imagen $\mathrm{y}$, sobre todo, la existencia de poemas-juego, lo que llama «ultraísmo puro» (Díez de Revenga, 2001: 103). Además resalta la influencia 
de las greguerías de Gómez de la Serna, cuyo magisterio es admitido por todos los poetas posteriores, aunque el poemario alonsino esté construido simbólicamente y no por medio de metáforas.

La visión poética del primer Dámaso Alonso se diferencia en gran parte de los preceptos estético-artísticos planteados por el grupo ultraísta del que tomará varios métodos constructivos. Por ejemplo, existe una propensión a la imagen y a la ruptura versal deliberada en la primera poesía de Borges (Borges, 1997: 142):

Las olas de rodillas

los músculos del viento las torres verticales como gritos

la catedral colgada de un lucero

la catedral que es una inmensa parva

con espigas de rezos

Lejos

Lejos

los mástiles hilvanaban horizontes

$\mathrm{y}$ en las playas ingenuas

las olas nuevas cantan los maitines

La catedral es un avión de piedra

que puja por romper las mil amarras

que lo encarcelan

la catedral sonora como un aplauso

que ondea.

Sin embargo, es incomparable con la apropiación y experimentación personal, en tono y forma (más tradicional), del espacio y las imágenes en la «Noche fría y serena de la calle de Carranza» (Alonso, 1981: 97):

Carranza es una levita

azul con botones blancos.

Delante de los estancos

el rojo y gualda tirita.

La escarchada se confita

sobre los desiertos bancos.

Azul con botones blancos, 
Carranza es una levita.

Se han retirado los onces

a la cama, pero entonces

pasa renqueando una $\mathrm{A}$

que mira con aire fosco

al lunático del kiosco

que ha tiempo roncando está.

Tose, expectora y se va.

Mientras que en el poema borgiano el sujeto desaparece entre la selva metafórica, la voz poética en los poemas alonsinos es clara y tiene un tono coherente en el transcurso del libro. El poema de Borges es un canto al progreso tecnológico y a la poesía autorreferencial, construida con metáforas, elemento constructivo poemático por excelencia. Los poetas ultraístas solo intentan crear imágenes novedosas a través de la separación completa de los dos polos de la misma para crear una sensación nueva y única. Al contrario, Alonso que, aunque utiliza juegos formales e imágenes ultraístas en su poema ${ }^{1}$, crea una poesía más personal y apegada a la tradición formal. Díez de Revenga (2001: 101-103) en su breve análisis de los Poemas puros admite que las imágenes de este poema son del más puro ultraísmo, ya que en él aparecen greguerías y rastros de una nueva visión del mundo citadino. La transposición de caracteres humanos a los trenes -la ebriedad, la tos- reafirman este tono humorístico desenfadado y alegre. Pero el humor no es de greguería (aunque sí ingenioso) y el tratamiento de los elementos tecnológicos no es ultraísta ${ }^{2}$. Es evidente que Alonso está experimentando con las formas (la disposición del texto) y la ruptura y explosividad de los poemas ultraístas le brindaron un camino para encontrar su voz poética.

\footnotetext{
1 En la primera versión del poema incluida en su Álbum (Aleixandre y Alonso, 1993: 27) la disposición de las estrofas era distinta: cada estrofa está situada en un lateral del papel. Además, el último verso «tose, expectora y se va» aparece en mayúsculas y en exclamaciones. Son estos juegos formales la influencia más directa del ultraísmo en el joven Dámaso Alonso.

2 Eso es así ya que la ciudad cosmopolita se convierte en uno de los temas predilectos de toda la primera poesía de vanguardia. La ciudad con un nuevo ritmo, con la apertura de nuevos espacios se presenta desde un punto de vista positivo y próspero para el ser humano. Sin embargo, en este poema la ciudad solo se intuye por los trenes que se pintan desde la mayor ingenuidad, conseguida y buscada.
} 
El joven poeta conocía los dogmas de la nueva poesía pero no se adscribe al grupo. Incluso en su «Poema ultraísta» la voz personal es más fuerte que el artificio, ya que la noche que se representa es observada por la voz poética a través del símbolo de la ventana abierta, recurrente a lo largo de todo el poemario. Sin embargo, las nuevas técnicas que impregnan estos poemas refuerzan un contenido visto por un individuo que se presiente. Los textos de Poemas puros no son solo poemas, como pretendían los poetas ultraístas.

Con elementos mínimos poéticos -es decir, lo único poético en un poema- conseguían crear un artificio alejado de todo elemento humano, realista. Años más tarde Ortega y Gasset lo retrataría con una sistematización magnífica (2008: 54):

Si se analiza el nuevo estilo se hallan en él ciertas tendencias sumamente conexas entre sí. Tiende: $1 .^{\circ}$, a la deshumanización del arte; $2 .^{\circ}$, a evitar las formas vivas; $3 .^{\circ}$, a hacer que la obra de arte no sea sino obra de arte; $4 .{ }^{\circ}$, a considerar el arte como juego, y nada más; $5 .^{\circ}$, a una esencial ironía; $6 .{ }^{\circ}$, a eludir toda falsedad, y, por tanto, a una escrupulosa realización. En fin, 7. ${ }^{\circ}$, el arte, según los artistas jóvenes, es una cosa sin trascendencia alguna.

El poeta debía perseguir el Vltra y llegar a las cotas más altas de ruptura y de novedad. Todo valía, y por ello nos encontramos con una nómina de autores que abarca y atrae todo elemento europeo de vanguardia ${ }^{3}$ para crear poemas con una misma resonancia. La novedad, la rapidez y estimulo de las ciudades, el pulso a favor de la modernidad técnica en todos los espacios humanos, la pérdida de la voz melancólica modernista en favor de una deshumanización, signan todos los poemas de estos autores ${ }^{4}$. Como vemos, llegan por otros caminos a las mismas ideas que los poetas puros, aunque en España los resultados fueran distintos: quieren crear poemas sin realismo ni humanidad. Y esta fiebre purista aparece en Poemas puros como una estética fugaz donde la visión del individuo es lo más interesante e importante. Como dice Fuentes Florido (1989: 50-54) la estética ultraísta ejercía demasiado culto a la forma por lo que los poemas estaban faltos de humanidad.

\footnotetext{
3 Y es que esa es la gran labor del grupo ultraísta: acercar la vanguardia europea (francesa, sobre todo) a los círculos literarios de España.

4 Como afirma Barrera López (1987: 21) la crisis de entreguerras crea una fuente de inspiración y de superación con la literatura anterior en los artistas de la naciente vanguardia en la que el mayor dogma era destruir todo lo anterior para construir una nueva poesía para un nuevo mundo dominado por la ciencia y la técnica a través de la metáfora.
} 
Todos estos poetas siguen la misma motivación de eclosionar el modernismo rubeniano ${ }^{5}$ favoreciendo una poesía nueva para un tiempo nuevo. El poeta se centra en un arte deshumanizado mediante el humor y la metáfora, cuya conjunción son las greguerías de Ramón Gómez de la Serna. El ser humano es desprovisto de todo elemento propio y, si se presenta, no es más que un ser sin personalidad en un entorno formal y lleno de estímulos novedosos.

En este impulso de libertad literaria surgen los primeros textos literarios de Dámaso Alonso. Aunque el poeta novel escribiera una poesía de carácter simbolista con toques de vanguardia, quiere alejarse completamente de la simbolización modernista sentimental, melosa y esteticista. En dos poemas del libro clama varias veces que hay que romper con el símbolo de la luna sentimental (Alonso, 1981: 98):

Racimos de burgueses.

Salidas de teatro.

¿Cuándo
sobaremos el lomo a las palabras
con la mano?
Ando
caído y cojo
y triste
y calvo.
¿Cuándo
romperemos, extáticos, la Luna,
amigo mío, hermano?

El sujeto poético, que ya se realiza improperios a sí mismo, típico en la poesía de Alonso, se deshumaniza entre el resto de personajes de la escena. Incluso asocia la pérdida de valores de la burguesía (a la que él pertenece también), ya que todos son retratados de la misma manera, a través de la cosificación. Ese no canto a la luna es contradictorio con la deshumanización

\footnotetext{
5 Aunque las huellas del modernismo existen en estos poetas, ya que la revista Grecia en sus primeros números recogía poesía y textos de carácter rubeniano. Pedro Garfias, uno de los mejores poetas del ultraísmo, tiene un cierto matiz y tono modernistas por la melancolía que presenta en muchos de sus poemas y porque es de los pocos autores que se interesa por temas metafísicos: el tiempo es el tema principal de su poesía, aunque tamizado por un filtro formal ultraísta.
} 
de los personajes, puesto que lo que pretende es despojar al símbolo de todo adjetivo afectivo y sentimental. La frase se vuelve a repetir en «Romanza sentimental» ampliando su significación (Alonso, 1981: 117):

Romperemos, extáticos, la Luna

en el cristal del agua.

Romperemos, extáticos, la Luna

blanca,

diciendo: “¡Vete ya, que te cantaron

bastante!... ¡Anda!"

Romperemos, extáticos, la Luna

en el cristal del agua,

y ella

-la pobre-

seguirá besándonos,

redondita, burguesa y empolvada.

En este caso la luna aparece con los atributos de una mujer burguesa y deshumanizada: el símbolo se personifica para romper con ello todos los ideales vanguardistas fríos e inertes. Parece que con esta presentación y ruptura del símbolo de la luna Alonso enmarca lo que para él es la poesía: ni un artificio sentimental y sonoro al estilo modernista ni un elemento aséptico sin aliento humano.

Pero, aunque en estos poemas no se encuentre un nivel de deshumanización y pureza tan alto como el de poetas coetáneos, tienen un aroma técnico y formal de primera vanguardia. Gloria Videla (1963: 110-116), en su clásico estudio sobre el ultraísmo, afirma que la concepción poético-estética de esta primera vanguardia se basa en dos resortes: la utilización de la metáfora-imagen y los juegos tipográficos. Como ya hemos afirmado, hay muy pocas metáforas e imágenes en el poemario, pero Alonso sí que experimenta con la conformación y lugar de las palabras en el espacio para crear motivos pictóricos, movimientos o sensaciones que en el papel, en primera instancia, no se pueden conseguir.

La visión pictórica del joven Dámaso Alonso se plasma en la presentación de escenas. En el caso del «Madrigal de las once» se plantea un espacio 
campestre en la que la novia, otro de los personajes simbólicos del libro, se deshumaniza y se presenta en una de las pocas imágenes vanguardistas del libro, casi irracional (Alonso, 1981: 112):

Desnudas han caído

las once campanadas.

Picotean la sombra de los arboles

las gallinas pintadas

y un enjambre de abejas

va rezongando encima.

La mañana

ha roto su collar desde la torre.

En los troncos, se rascan las cigarras.

Por detrás de la verja del jardín, resbala,

$$
\text { quieta, }
$$

tu sombrilla blanca.

En este poema encontramos una estampa alejada del mundanal ruido, en un paisaje de corte campestre en el que el sujeto no forma parte de la escena completamente, en un estado casi de somnolencia y de sugerencia dado por el ambiente vivo que se centra alrededor y la imagen del collar cayéndose al modo de las campanas (una de las pocas imágenes del libro). Al final, aparece la novia, totalmente desposeída de elementos humanos. Se la representa solamente a través de la sombrilla blanca que lleva consigo. Pero lo realmente interesante de ese último endecasílabo es el carácter pictórico que se dota a la imagen por la ruptura escalonada del mismo. Al fraccionar el verso en forma de cascada, escalonada, y unirlo con el verbo «resbalar» propicia y crea un sensación de movimiento que refuerza al propio lenguaje.

En el caso de «El descanso» (Alonso, 1981: 85) el verso fraccionado de manera escalonada responde a conseguir la calma y serenidad del locus amoenus:

-Hogar.

Paisaje.

Otoño. 
Río manso.-

Y, en el reloj del muro, el Sol ponía

la irreparable hora del descanso.

Alonso en su juventud experimenta más que con el lenguaje, con la disposición del mismo para crear nuevas sensaciones, tal y como los ultraístas estaban haciendo en sus poemas ${ }^{6}$. Con esta disposición versal el poeta pretende crear sinestesias visuales no con el lenguaje, sino con la forma. Alonso se apropia de esta técnica y como ejemplo máximo de esta experimentación el poema «Música callejera»: (Alonso, 1921: 69-70):

Él toca. Ella canta violín cansado de peregrinar
El músico, ciego.

Cantora preñada, cara variolosa voz turbia y agraz

Balcones abiertos.

Tarde de domingo

-Domingo redondo

Y bobalicón.

El cobre roñoso

era un Luis, dorado

a un hilo del sol.

El librote, abierto;

Sombra violeta
café de la esquina,
dormida ciudad
¡violín mugriento,
violín cansado
de peregrinar!

Chirirí-riraro tirarí-rirera ¡Pobre violín! tarde estudiantil

\footnotetext{
Alonso decide eliminar el poema en la edición posterior de 1981. En él se mezcla tradición -versos en arte menor- con una disposición tipográfica inusual, novedosa y moderna, fiel a la estética ultraísta. Al contrario, el motivo

6 Rosa Ma Martín Casamitjana (1996: 426) asocia el concepto de humor con la disposición tipográfica de estos poemas. No por su efectismo, ya que defiende la intención no humorística de crear una nueva sensación. Sin embargo, pragmáticamente, el receptor no entendía estos poemas nada más que como juegos pueriles y, por simple sentimiento de superioridad, tildaba estos poemas como experimentos sin sentido.
} 
de este juego poético no es más que el de presentar varias escenas simultáneas en el papel simulando instantaneidad: la música, los intérpretes y los estudiantes sentados en el jardín escuchando el mal uso del violín. Esta mezcla de forma vanguardista y plasmación de los hechos de forma tan económica y limpia, junto con una forma de tipo tradicional aporta un significado a los tempranos poemas de Alonso. Estas características son las que signan a su grupo poético. Aunque haya textos centrales como Marinero en tierra de Alberti o Cántico de Guillén, ya se perciben estas técnicas en un libro anterior de un autor que se considera más crítico que poeta en su propio grupo.

Este juego con la versificación tampoco es propia de los primeros autores de vanguardia: la disposición de versos de una sílaba ya aparece en Manuel Machado o Valle-Inclán. Dámaso Alonso también los utiliza por distintas razones: con la intención de remarcar un vocablo para dar significación al texto como en el segundo poema de «Poemillas del viajero», en el que al resaltar la primera palabra (que junto con el siguiente verso forma un endecasílabo perfecto) crea un efecto de ampliación de significado en el poema. Todo es igual, y el poeta lo retrata así (Alonso, 1981: 86):

Igual.

El patio, el pozo, las hortensias

y el huertecillo diluido al fondo.

Dejó el bordón y meditó un momento.

Mas, el otro,

igual a él, calzaba las sandalias

para el camino.

Sin embargo, hay ocasiones en el que el verso de una sola palabra (o dos) sirve para reflejar una realidad amplia con el menor número de palabras. Este proceso de depuración de la palabra ya existe en la poesía española desde Bécquer, pero se amplía en la poesía moderna, ante un acto de contención de ideas desde una forma prefijada (Alonso, 1981: 96):

\section{LA UNA}

La terraza.

En tus ojos

la ciudad se ha dormido.

Acariciamos, tácitos, palabras que enlazadas diferimos. 
De pronto

hablamos y reímos:

la ciudad en tus ojos

despierta sin sentido:

cosas

1905.

Y retiran, borracho, a su cochera,

al último tranvía del Domingo.

No hacen falta más palabras para crear la escena. Además, todos los poemas del libro parece que se pergeñan en un estado de sugestión y de creación de fragmentos, cuya significación o no se remata, o tiene que figurársela el lector. En cuanto al contenido los poemas están relacionados entre sí, pero se abre la ventana del significado, porque no están finalizados con una frase o por una imagen: Dámaso Alonso crea estampas sugerentes y realistas (lingüísticamente) desde el punto de vista de una voz poética con miedos, pensamientos y debilidades.

Este tono de voz melancólico y receloso por salir al exterior de su «rincón feliz», según José Ángel Cilleruelo (1990: 115), también se aprecia en la disposición, a veces caótica, de los versos. El autor con la ruptura del verso quiere transmitir la sensación de melancolía o de dolor del sujeto poético (Alonso, 1981: 93):

\section{LOS CONTADORES DE ESTRELLAS}

Yo estoy cansado.

Miro

esta ciudad

- una ciudad cualquiera-

donde ha veinte años vivo.

Todo está igual.

Un niño

inútilmente cuenta las estrellas

en el balcón vecino.

[...] 
La sensación de ahogamiento y hastío del sujeto en la ciudad no se traspasa solo a su espacio observable, sino que sobrepasa los límites del espacio creado, para acudir al papel con la inestabilidad tipográfica del verso que el poeta había aprendido en los poemas ultraístas de las revistas Grecia y Ultra.

\section{2. ¿LITERATURA NAÍF EN POEMAS PUROS?: JUEGO Y HUMOR}

Los Poemas puros, poemillas de la ciudad son, como ya hemos advertido, un conjunto de poemas de su tiempo y del tiempo interno de su autor: mezcla de simbolismo moderno con experimentación propiciada por la primera vanguardia española y europea. Pero, al contrario que la primera generación vanguardista, Dámaso Alonso se vale de la poesía tradicional y de sus formas para crear una voz poética diferente a la de su nuevo contexto artístico. En la década de los años veinte existen cuatro grandes movimientos que aúnan los poetas de la Generación del 27, interconectados entre sí: el ultraísta, el purista, el gongorino y el neopopular, en la que también puede encuadrarse al primer Dámaso Alonso. Entre los títulos más importantes de esta poesía popular, tradicional, incluso lúdica y humorística, se encuentran el Marinero en tierra de Alberti y el Romancero gitano de Federico García Lorca. Pero, en palabras del mismo Alberti, es el libro de Dámaso Alonso el que abre las puertas de este tipo de poesía que aúna un tono y forma tradicional ${ }^{7}$ pero con un punto de vista moderno, novedoso en la aparición de lo lúdico (Alberti, en línea):

Ya digo en la primera parte de «La arboleda perdida» que Dámaso era un joven de prematura madurez, con un extraordinario talento, pero que padecía de desilusión, de una incomprensible falta de seguridad en sí mismo, rayana a veces lo trágico. El libro que me llevaba, por su temblor humano, extremada economía de expresión y sencillez, abrió cauces hacia la gran poesía de aquella década.

Esta utilización de los metros tradicionales es además uno de los síntomas creativos de los poetas del gusto más puro. Pero esta vuelta a la versificación clásica se debe, en gran parte, al cansancio del versolibrismo de la pronta

7 Soria Olmedo recuerda que «todos estos síntomas revelan una actitud general de sintonía con la "llamada al orden" ("rappel à l'ordre") que lanzó Jean Cocteau en su ensayo sobre música Le coq et l'arlequin (1920)» (2007: 57). 
vanguardia, junto con la influencia de Machado y Jiménez. Por otra parte, la fijación de una idea, depurada totalmente, en un esquema prefijado -ya que la forma era una permanente teórica de lo poético junto con la metáfora- es una de las constantes de todas las corrientes vanguardistas en toda Europa. Por ello, el dominio de las formas clásicas supone para estos poetas un esquema prefijado para componer una idea. Se renuevan las formas con un propósito de modernidad. En la poesía de entreguerras es esencial la caracterización de lo lúdico, del juego interno en el propio poema, creando, a partir de la falta de anécdota, juegos formales y solamente poéticos. Aunque Dámaso Alonso en uno de sus poemas, «Motivo viejo y sentimental» utiliza este tono lúdico con una intención meditada y no con una motivación de artefacto: mediante la ironía (Martín Casamitjana, 1996: 47):

Dón...!

$$
\text { Dín...! }
$$

Dán...!

Doblando las campanas van.

¿Adónde irán?

Dín...!

Dán...!

Dón...!

Doblan en mi corazón.

-Dón...!

$$
\text { Dán...! }
$$

Dín...!-

colorado y chiquitín.

El lenguaje real y no artificioso (muy usual en toda la obra alonsina) junto con la asonancia, crea la idea de depuración en el poema y el sonido de las campanas propicia un tono lúdico muy poco visto en la poesía anterior. Esa vuelta al lenguaje sencillo (Soria Olmedo, 2007: 57) es posible por el interés en la tradición y al carácter popular de las canciones de la poesía medieval y de los Siglos de Oro, pero también a los romances de ciegos y a los poemas becquerianos y de Antonio Machado que ya había leído Dámaso Alonso. Además, es clara su inclinación hacia la lectura y aprendizaje a través de clásicos: el propio poeta (Zorita, 1976: 19-20) comenta que sus primeras lecturas en la escuela fueron autores clásicos españoles de los Siglos de Oro hasta Espronceda. 
Esta relación con el juego, con lo lúdico que se realza con las formas populares y tradicionales tiene el nombre de literatura naíf. El Diccionario panhispánico de dudas dice de esta estética que es el: "[Arte o artista] que se expresa con ingenuidad deliberada, imitando la sensibilidad infantil» (DPD, en línea). Esa ingenuidad deliberada se conforma a través del humor y de las formas y metros tradicionales, pero es premeditadamente fruto del pensamiento del autor. En el poema anterior, el humor y la ingenuidad le sirven a Dámaso Alonso, de manera irónica, para responder y atacar el tratamiento sentimental y vacío de la literatura anterior. Aunque Alonso escribiera una poesía personal y humana no quiere rayar con el patetismo estético ni con la deshumanización plena de las nuevas estéticas de vanguardia. Un ejemplo de esto es el poema «Noche» de la sección «Poemas puros» (Alonso, 1981: 82):
Y caen de las estrellas los sueños altos.
Si vienen a la tierra, Se volverán llorando.
Se volverán llorando, el caminito arriba.

El matiz lúdico se configura a partir de un esquema tradicional (versos de arte menor, asonancias) pero es el tono de la voz poética el que construye la atmósfera melancólica. El sujeto, pesimista, ve la imposibilidad de cumplir sus sueños ya que, aunque caigan del cielo, volverán con la tristeza de vuelta, tras visitar el mundo real, el mundo de las cosas, el espacio exterior al rincón feliz. El tono fatalista favorece la lectura de incapacidad vital que ampliará sus resonancias en su poesía de posguerra. Este tono melancólico está matizado por la apariencia popular y tradicional, siendo esta forma la idónea para su contenido.

La poesía de tono lúdico está asociada a la alegría deportiva del ultraísmo y al alejamiento de lo humano. Sin embargo Dámaso Alonso se permite utilizarlo para el sentido contrario, influyendo así a los poetas de su mismo grupo. Pero todo ello, tal y como aparece en el título del libro, le sirve al joven poeta para revestir sus poemas de una pureza más formal (metros tradicionales) que de contenido. Aunque los poemas de Alonso son depurados lingüísticamente, no es más que una marca de estilo realista. Lo importante 
es que esa forma tradicional sea el propósito para crear poemas estéticamente puros, «claros, tersos», como explica en su poema «Dedicatoria final (las alas)» (Alonso, 2013: 173-174). Y es que ese retorno a la tradición está completamente unido a las ideas vanguardistas de la misma época: purismo y alegría juvenil o en palabras de García Montero es un «mecanismo ideológico significativo por el cual la tradición puede utilizarse como fórmula de vanguardias, como un modo de continuar la tradición selectiva» (Alberti, 1988, I). Ese «clasicismo moderno» como afirmaron Gerardo Diego y Bergamín (Geist, 1980: 137) solo sirve para los propósitos vanguardistas y modernos. Prefieren a Góngora y no a Garcilaso, a Soto de Rojas y no a Herrera... lo obscuro pero con una poda expresiva.

También afirma Geist (1980: 43) que se trata de volver a las antiguas formas para retratar unas nuevas realidades que no permitía la estética desgastada del ultraísmo. Por esa misma razón, Alonso se vale de las técnicas, pero desde un punto de vista más personal para retratar espacios y escenas como trasunto del estado anímico de la voz poética (Alonso, 1981: 108):

\author{
NOVIA, si eres triste, novia; \\ novia, si eres triste, mía: \\ toma la estrella pequeña \\ de mis poemillas. \\ Mira, me la dio mi madre, \\ porque yo era bueno, un día... \\ Y yo la puse en mis versos... \\ ipues te la regalo, mira!
}

Novia, si eres triste, novia.

Esta nueva «poética de lo breve», como la denomina Geist (180: 142-143), es también un punto en común entre la tradición y la vanguardia. La utilización de las formas tradicionales le permite a Alonso crear unos poemas sintéticos y, en ese sentido, puros, pero indefinidos, semánticamente incompletos en el que la expresión bipartita de melancolía y alegría juvenil son el centro de su significación. Es en esta actitud donde se aprecia el valor de la modernidad de estos poemas. Alonso en sus primeros acercamientos a la poesía mezcla todos sus conocimientos lectores, cuyo resultado es una obra estéticamente novedosa. 
Es extraño encontrar una voz tan personal e individual en su momento donde lo puramente científico y lo deshumanizado primaban ante lo sentimental y lo personal. En estos poemas hay lugar para lo humano: el estado de ánimo del sujeto poético evoluciona desde un breve optimismo hasta una gran melancolía. Esa diferencia se debe al paso de un espacio interno, salvo y otro externo que no es seguro para la voz poética (espacio puro frente al espacio citadino). La ciudad no es real, es vista desde unos ojos que recuerdan, que abren los espacios desde el prisma de un ser-parala-muerte. Todo esto se relaciona con la juventud de Alonso en la que tuvo una crisis de fe que se aprecia en el tono del libro (Zorita, 1976: 30-31). La búsqueda de una novia imaginaria es el vínculo del paso de la niñez a la edad adulta, pero no es real ni se busca, lo que crea en la voz poética una desazón que se plasma en los últimos poemas, donde el tono popular, naíf y, sobre todo humorístico, se refuerza y el sujeto solo quiere ser un prestidigitador, un clown.

El humor de un joven Alonso, irónico y burlesco (Aleixandre, 1958: 9199), según las apreciaciones de Rosa María Martín Casamitjana (1996: 2430), es humorismo y no comicidad. Lo cómico es lo «erróneo, incongruente». Produce risa por la incoherencia, no solo del sentido, sino pragmática. Esto ocurría con los poemas ultraístas, ininteligibles por la mayoría del público que, por esa desconexión con el referente o con la estética, carcajea por superioridad moral y cognoscitiva (Martín Casamitjana, 1996: 420). Es un humor intelectual, en palabras de Freud, ya que la emoción castiga al humor y lo reemplaza a otro nivel. Es algo artificial, mientras que el humorismo, categoría con la que podemos relacionar estos poemas, es lo cómico, pero con rastros de humanidad, emoción y sentimientos, en este caso pesimistas $^{8}$. El humor lúdico del que se reviste la voz poética traspasa los niveles del mismo por y para el poema, a fin de retratar un estado de ánimo de hastío y de melancolía. Parece que el sujeto de los poemas, al darse

\footnotetext{
8 Martín Casamitjana (1996: 428) aporta una nota muy interesante. El humor y la ironía según las teorías de vanguardia, respaldadas en 1925 por Ortega y Gasset, son bases en las que se apoyan para crear el efecto de deshumanización progresiva. Sin embargo, el humor es algo interno al hombre, recubierto por resortes humanos para su significación. Si se elimina ese elemento humano del humor se convierte en un artificio que solamente puede comprenderse en un círculo cerrado. Ese humor sectario lo único que puede producir es risa satírica por parte del que no lo entiende, del que está alejado de los puntos de referencia que permiten su comprensión. En los poemas alonsinos el humor deshumaniza, pero para dar cuenta de esa falta de valores producida por la melancolía y el dolor. El humor y la forma están acorde con el contenido de los poemas: existe como realce del tono pesimista.
} 
cuenta de la dureza del mundo, del espacio citadino, decide obviarlo todo, parece que le es igual, y se convierte en un clown sentimental (Aleixandre y Alonso, 1993: 26):

Yo soy un clown sentimental,

mi novia es guapa

y tengo el alma escondida en el ojal

de la solapa.

Pero el humor de todos estos poemas reside en que existe algo de inteligibilidad y que hay un sentimiento de dolor y de resignación latente sin ningún toque de ingenuidad (aparente), aunque el humor llega a través de una deshumanización poco notorio. Esto ocurre porque, en los últimos poemas, la voz poética aparece carente de todo elemento humano, solo se dedica a resignarse y a ser un bromista, a hacer juegos y piruetas, a ser un prestidigitador, a cantar la alegría del desconocimiento del mundo, para llegar, de nuevo a la felicidad, alejado de todos los relatos externos.

La deshumanización es del alma y cuanto más pesimismo existe en el yo de los poemas, más se aleja de sí mismo, de su espacio y de los demás. En el entorno de la ciudad las cosas (trenes, casas, calles, banderas) empiezan a personificarse y embriagarse por creación de los ojos cada vez más cosificados. Por esa razón el sujeto y los seres humanos se describen sin ningún ápice de humanidad. En el personaje lo único que sabemos es que tiene un tono pesimista y que es «viejo, triste, calvo». La burguesía a su alrededor se dispersa en racimos, los personajes del cementerio están más muertos que los enterrados y los seres humanos de la ciudad se representan a través de sus acciones a pinceladas. El humor de carácter ingenuo (pero muy meditado) sirve para realzar ese dolor, esa melancolía que conduce a la voz poética a una deshumanización de su alma.

Ese pesimismo se reafirma con el efecto de humanización para deshumanizar (Martín Casamitjana, 1996: 256). Pero consigue lo mismo al apropiar caracteres negativos a las cosas humanizadas, como el miedo o la ebriedad de los trenes de la noche en Carranza. El sujeto poético pretende eclosionar el símbolo de la luna en un acto de ruptura con la estética anterior. Tanto es así, que asocia este símbolo con el de una mujer burguesa. Humaniza para, en contraste con la burguesía-racimo, deshumanizar el símbolo y des- 
prestigiarlo más, creando una imagen naíf y humorística como vimos en «Romanza sentimental».

\section{CONCLUSIONES}

El matiz humorístico de estos poemas debe asociarse al tono infantil, popular y tradicional que se personifica en el estado de ánimo y la evolución circular del sujeto. Por otra parte, el humor no se asocia a la risa sencilla que signaba las creaciones poéticas del grupo ultraísta. El humor de los poemas alonsinos tiene rasgos formales vanguardistas y ultraístas porque era consciente de las novedades. Sin embargo, su uso tiene un sentido diferente para conformar el tono del libro. El arlequín, el clown, son figuras que aparecen ya en Manuel Machado y el decadentismo español y europeo. Pero Alonso los toma como recipiente vacío donde emplazar los sentimientos de la voz poética. El humor parece residual, ingenuo a primera vista, pero redondea significativamente unos primeros poemas muy maduros en conformación técnica y de contenido. Ese tono pesimista es demasiado humano para las estéticas de la primera vanguardia española. Alonso lo sabe y conoce la nueva poesía de la que toma elementos técnicos como la disposición versal para su propio beneficio. De esta manera Poemas puros, poemillas de la ciudad es un libro donde se recogen las estéticas cercanas a la época de juventud de Alonso. Pero no son calcas exactas de sus lecturas, sino que aparece marcada la voz propia del poeta. La disposición versal sirve para crear poemas pictóricos y las pocas imágenes que existen son de carácter ultraísta, aunque resuenan ecos melancólicos y pesimistas demasiado humanos para las primeras estéticas de vanguardia.

\section{REFERENCIAS BIBLIOGRÁFICAS}

Alberti, Rafael (1988), Obras completas, Tomo I. Poesía 1920-1938, Madrid, Aguilar, pág. I.

AlberTI, Rafael (1990), «Un joven de prematura madurez», en Diario ABC, 26 de enero de 1990, p. 59 (Sección "La muerte de un maestro del idioma"). En línea: http://hemeroteca.abc.es/nav/Navigate.exe/hemeroteca/madrid/abc/1990/01/26/059.html. Último acceso el 18-nov-2018. 
Aleixandre, Vicente y Alonso, Dámaso (1993), Álbum. Versos de juventud, Barcelona, Tusquets.

AleiXandre, Vicente (1958), Los encuentros, Madrid, Guadarrama.

Alonso, Dámaso (1921), Poemas puros. Poemillas de la ciudad, Madrid, Galatea.

- (1969), Poetas españoles contemporáneos, Madrid, Gredos.

- (1981), Gozos de la vista. Poemas puros. Poemillas de la ciudad. Otros poemas, Madrid, Espasa-Calpe.

- (2013), Hijos de la ira, Barcelona, Austral.

Barrera LóPez, José María (1987), El ultraísmo de Sevilla, Tomo I-II, Sevilla, Alfar.

BONET, Juan Manuel (1995), Diccionario de las vanguardias en España: (19071936), Madrid, Alianza D.L, 44-45.

BorGES, Jorge Luis (1997), Textos recobrados. 1919-1929, Barcelona, Emecé.

Cilleruelo, José Ángel (1990), «De la calle del arrabal al millón de cadáveres. Poesía de la ciudad en Dámaso Alonso», en Revista Anthropos, 106/107, págs. 115-117.

DPD, Diccionario panhispánico de dudas. En línea http://lema.rae.es/dpd/srv/ search?key=na\%EDf Último acceso el 13-nov-2018.

Díez de Revenga, Francisco Javier (2001), La poesía de vanguardia, Madrid, Ediciones del laberinto.

Fuentes Florido, Francisco (1989), Poesías y poética del ultraísmo: antología. Estudio preliminar y selección por Francisco Fuentes Florido, Barcelona, Mitre D.L.

GeIsT, Anthony Leo (1980), La poética de la generación del 27 y las revistas literarias: de la vanguardia al compromiso (1918-1936), Barcelona, Guadarrama.

Martín Casamitjana (1996), Rosa María. El humor en la poesía española de vanguardia, Madrid, Gredos 
ORTEGa y GASSET, José (2008), La deshumanización del arte y otros ensayos de estética, Madrid, Espasa Calpe.

SORIa Olmedo, Andrés (2007), Las vanguardias y la Generación del 27, Madrid, Visor.

VIDELA DE RIVERo, Gloria (1963), El ultraísmo: estudio sobre movimientos poéticos de la vanguardia de España, Madrid, Gredos.

Zorita, Ángel (1976), Dámaso Alonso, Madrid, Epesa. 


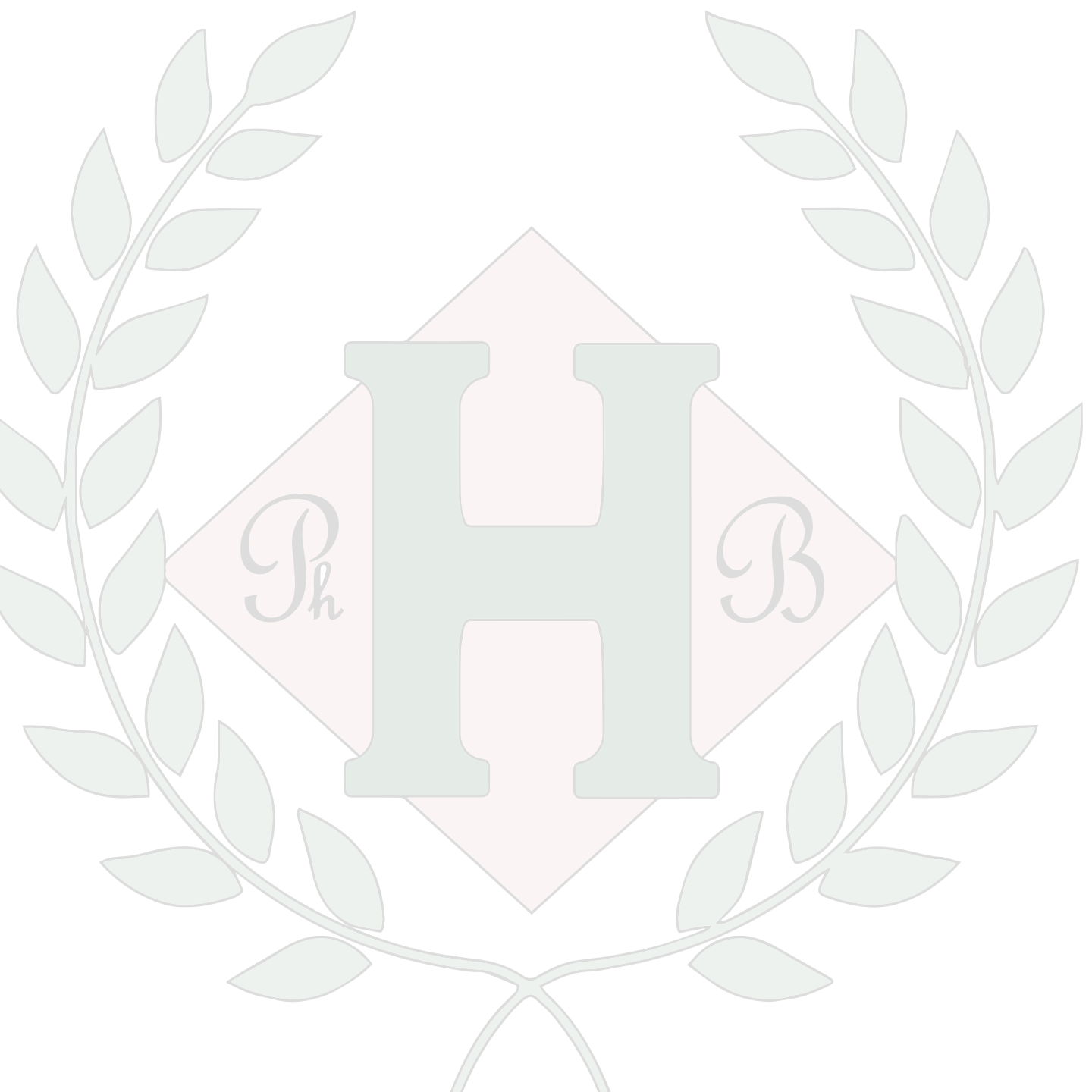

